\title{
THE 'DRAGON' AND THE 'ELEPHANT' AND GLOBAL IMBALANCES
}

\author{
Max Spoor \\ $2010 / 29$
}

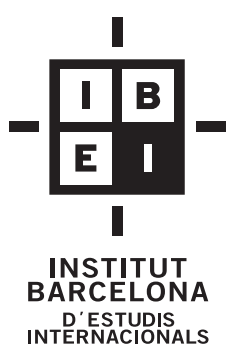

Max Spoor

International Institute of Social Studies, The Hague / Erasmus University Rotterdam (EUR)

Institut Barcelona d'Estudis Internacionals (IBEI)

spoor@iss.nl 
IBEI WORKING PAPERS

2010/29

The 'Dragon' and the 'Elephant' and Global Imbalances

(C) Max Spoor
(c) IBEI, de esta edición

Edita: $\quad$ CIDOB edicions

Elisabets, 12

08001 Barcelona

Tel. 933026495

Fax. 933022118

E-mail: publicaciones@cidob.org

URL: www.cidob.org

Depósito legal: B-21.147-2006

ISSN:1886-2802

Imprime: Edugraf S.L.

Barcelona, April 2010 


\title{
THE 'DRAGON' AND THE 'ELEPHANT' AND GLOBAL IMBALANCES
}

\author{
Max Spoor
}

\begin{abstract}
Global financial imbalances receive a great deal of attention in relation to the emerging economies China and India. This chapter analyzes this relation, but argues first that they are actually re-balancing the existing structural inequality in the world economy, in which for so long only the Western economies and Japan dominated economic growth and international trade, moving towards a more multi-polar world economy. China in particular, with its rapid export-led growth, has indeed been part and parcel of the emerging financial imbalances, feeding the 'over-consumption' in the US and using its accumulating international reserves in buying US-treasury bonds. Finance therefore is moving to the economy that 'least needs it'. This imbalance can only be redressed if the US (and some of the other OECD countries) start saving more and consuming less (and become more competitive), with China further stimulating domestic demand (which it already did in response to the crisis). China and to a lesser extend India, as emerging large economies and with more important roles in global markets, also contribute to new imbalances, such as the influence of the insatiable appetite for resources (carbon-hydrates, minerals and bio-mass) of these relatively energy-inefficient economies, while at the same time attracting an increasing share of FDI towards them. The chapter finally raises the issue that these three mentioned imbalances make it more difficult for developing countries (except for those who are resource-rich) to get access to the necessary development finance.
\end{abstract}

Key words: Economic Growth, World Trade, Global Imbalances, China, India

Acknowledgements: This paper benefitted from detailed comments by Alex Izurieta, Mansoob Murshed and Pedro Goulart. I also gratefully acknowledge the research support received from Koen Voorend and Marijn Nieuwenhuis. 


\section{Introduction}

This paper analyses the complex manner in which the emerging developing economies of East, South and South-East Asia (in particular China and India) have been influencing the main imbalances in the world economy before the global economic crisis and after, how the global crisis has affected them, and how in particular the 'Dragon' (China) and to a lesser extend the 'Elephant' (India) stimulate the world economy's recovery. It will be argued that 'developing Asia' is contributing to the rebalancing of a highly unbalanced world economy, but with its spectacular growth it was also part and parcel of growing global financial imbalances, while furthermore causing new ones to emerge.

Global imbalances are the outcome of growing unequal trade flows, caused by an insatiable US-consumer demand, fed by cheap Asian consumer goods and other exports, leading to a high trade and a growing current account deficit, which is financed by the purchase of US treasury bonds and other Dollar nominated securities by private investors and Asian governments. However, the world economy has known another, more fundamental imbalance as the US-economy has been for long the largest economy, also dominating world trade (with the EU and Japan) in the past century, in which most trade was actually originating in and destined to industrialized high income countries (Ocampo and Martin, 2003). Furthermore, as an outcome of this traditional dominance of the US economy, the US-Dollar functions as a reserve currency. As countries, such as the emerging Asian economies that are greatly dependent on trade and finance, wish to shield themselves from external shocks and exchange rate fluctuations, they accumulate dollar reserves, creating the necessity for the US to run ever larger deficits.

The very high growth rates of 'developing Asia', and in particular China started to redress some of this structural imbalance. During of decade of the 2000s China and India together were rapidly approaching the size of the Japanese economy, which for long has been the second economy in the world in size. By 2010 China is overtaking Japan in size, confirming its role as a major player at the world's stage, although still following the USeconomy at a sizeable distance (see Table 1). Therefore, the world economy is changing from one which was fully dominated by the OECD economies, towards a multi-polar one with various large economies, including China. The role of India might become important in the near future, but its growth model has been structurally different (and with growth rates that were substantially lower than the Chinese ones), as it has been largely based on growth of internal consumption rather than exports (such as is the case in China). Dollar (2009) confirms this point of view by arguing that the current century will become a "multi-polar century" rather than an "Asian century", which is sometimes being suggested (Mahbubani, 2008), as the size and exports of the other Asian developing economies (including India) are much smaller than China as yet.

World trade is also changing substantially, as a much greater volume of merchandise and services is now exchanged in Asian markets (if compared with the early 1990s when China started to focus on external trade). Again this effect is particularly caused 
by emerging Chinese exports (and imports), although we should not ignore that Chinese exports are often still dominated by (Western-based) multinational companies (Fischer, 2009). Asia as a whole by 2007 was already the second largest 'trade block' in the world (see Table 2), particularly stimulated by spectacular growth rates of Chinese trade volumes. While this contributes to redressing the first mentioned more structural imbalance in the world economy, at the same time it has fuelled the emerging global financial imbalances, as some Asian economies (in particular China) became the main supplier of the American consumer goods market, while the accumulated reserves (as outcome of the huge trade surpluses of China) emerged as the main funder to cover the growing UScurrent account deficit. Hence, emerging China contributed to these global imbalances in the form of 'cure' and 'cause' of the problem.

Next to these developments, the chapter will also show that Asia's growth (fuelled by the spectacular emergence of China), and its recent appearance as a major world player is also contributing to a number of new imbalances. These are, firstly, the growing appetite for energy, hydrocarbons and metals, which has been driving up world market prices. China and India are both relatively energy inefficient economies, hence high growth rates translate in much higher incremental energy demand than the OECD countries. Energy inefficiency in India is mainly due to weak infrastructure, while in China it is primarily caused by the many -energy inefficient- industries. While China and India both already represented an important part of the incremental demand for hydrocarbons and mine products in the past years (see Figure 2), also their overall volume of demand for energy has become substantial, and has a major influence in the world market prices for hydrocarbons.

Secondly, until the global financial crisis a marked differentiation started to appear between a number of current account surplus countries (mostly in Asia, except for India) and current account deficit countries (the Western economies, except for Germany). This has led to a growing concentration of international reserves, with China and Japan dominating the scene, holding more than half of the global volume of international reserves. These are not used to stimulate domestic investment or consumption, but 'hoarded' in the form of US treasury bonds, in part to defend themselves against external shocks and currency speculations. As a consequence, finance flows to the richest economy, namely the US. Also Russia, as the main exporter of oil and natural gas in the world, accumulated large international reserve holdings, especially after the price hikes in oil market during 2008.

There was also a shift in FDI flows, now that more and more FDI is moving to these rapidly growing economies, bypassing the rest of the developing world. Moreover, renewed bilateralism has been entering in international relations, in particular where China wanted to guarantee its current and future energy supplies. Some of these bilateral agreements, such as between China and African countries have included substantial funding for investment and development projects, in particular in infrastructure, counter-balancing the negative influence from diminished development finance (see Haan, 2009), but leaving aside the resource-poor economies in the developing world. While in the past some of the surpluses in one OECD country was 
'recycled' in portfolio investment in a deficit OECD country, this venue is not possible for China, which has not much other alternative than to use most of the reserves to buy US treasury bonds. ${ }^{1}$

Overall, it is argued here that with the emergence of China, and to a lesser degree of India, a process of structurally re-balancing the world economy has initiated, but the differential growth processes (with a slow growing non-saving importing US, versus a non-consuming exporting China) currently produce and worsen global imbalances, while also causing other ones. This development has already led to reduced access for the poorer developing countries to capital flows, as the latter are pulled towards the US, other Western economies or recycled between financial institutions in high income and countries before reaching the LDCs. The global crisis even seems to aggravate this picture, with the Western economies running into even larger fiscal deficits, while the emerging Asian economies are partly more focusing more on their own recovery.

Indeed, since the Asian and Russian crises of the late 1990s, the growth rates of nearly all Central, East, South and Southeast Asian economies became sustained and very high. The Chinese economy experienced an even much longer path of such spectacular growth, which has been uninterrupted since the early 1980s. The performance of large Asian (developing) economies, such as China and to a lesser extend India, although in size still smaller than the US, EU and Japanese economies, pulled the chart of growth during the past decade, particularly as Japan has been stagnating during most of that same period.

The growing importance of the emerging Asian developing economies (next to the traditional role of Japan) seems to redress part of a longstanding imbalance in the world economy. In fact, global economic power has been dominated since the mid-1800s by Europe and the United States. With the strong recovery of Japan in the second half of the $20^{\text {th }}$ century and in spite of the successful emergence of the Asian Tigers (such as South Korea and Taiwan), the high income OECD countries (including Japan) still largely dominate the world economy and world trade.

This highly skewed economic development, with wealth concentrated in fairly small areas of the world, seems now to be gradually but steadily transforming. By 2007 the Chinese and Indian economies together were close to the size (measured in Gross National Income (GNI) at market prices; see Table 1) of the Japanese economy, while already being substantially larger if measured at Purchasing Power Parity (PPP) prices. By 2010 the Chinese economy has become larger in size than the Japanese economy, becoming the second economy in the world. ${ }^{2}$ Of course, with regards to per capita incomes there are still huge inequalities, but if only taking the total size of these economies, the highly unbalanced world economy has been indeed been changing. Over the past two decades this was particularly influenced by the developments in international trade un-

1. This point was made by Alex Izurieta in a personal communication, indicating that FDI is much less symmetrical than in the past.

2. The data of IMF (2009), published in April, has been used here. 
til the global crisis started, in which particularly China has become an important new player. Furthermore, China has become a formidable player in international political relations on the world scene, and is an exponent of 'soft power' (Haan, 2009).

This paper analyses the growing importance of Asia in the world economy as follows. In the second section, we will show that the rapid growth of the economies of Central, East, South and Southeast Asia, leads to at least a partial redressing of the existing structural imbalance of the world economy. It also briefly looks to how the global crisis influences China and India, and how a resumption of rapid growth in these countries might 'pull' the world economy out the recent deep recession.

In the third section, the spatial shifts in international trade are addressed, which has seen a transformation in particular since the late 1990s, from a predominance of intra-high income country trade towards a growing role of trade originating from low- and medium income countries. This is primarily caused by rapidly expanding merchandize trade of China (Dollar, 2009; Acharya, 2009). In this section also the influence of the increased appetite for hydrocarbons and metals by the rapidly growing developing economies of Asia, in particular China and India, is being discussed.

In the fourth section, we will analyze global financial imbalances that have emerged, in particular the current divide between Current Account (CA)-deficit and CA-surplus countries, with a growing concentration of international reserves in the hands of some of the Asian economies (such as China and Japan), and look at its effects, and what influence the global economic crisis has in this respect.

In the concluding section it will be stressed that the growth of China and to a lesser extent of India is influencing existing and new global imbalances. It will concluded that there is an important negative impact the much slower growing (and often resourcepoor) rest of the developing world, in particular looking at the inverse flow of finance (from fast-growing China to slow-growing US), the availability of FDI, its overall significance for development finance and the rising energy prises caused by rapidly growing additional demand for carbohydrates and bio-fuels by China and India.

\section{The 'Dragon' and the 'Elephant': Stabilizers of the crisis?}

While Japan has been the largest Asian economy for several decades, it suffered stagnation since the Asian crisis of the late 1990s. China's sustained and high growth rates have meant that by 2007, its GNI at market prices had reached the size of 64.7 percent of the GNI of Japan (Table 1, based on the World Development Indicators of the World Bank). According to the IMF in 2010 the Chinese economy has overtaken 
the Japanese as second economy of the world, although if we compare import and export shares of China (in the world total) with the US and Europe, these data somewhat overstate the importance of China. At the same time, the US economy has been loosing its global dominance, representing 26.3 percent (at market prices) of the world economy in 2007, and 'only' 21.0 percent at purchasing power parity prices, although still by far remaining the largest single economy of the globe (see Table 1).

Although in 2007 (on the eve of the global crisis) the OECD countries still represented the largest share of the world's GNI, namely 71.5 percent (in PPP terms 54.2 percent) the balance is indeed changing, and the traditionally unbalanced income distribution (between countries) is partly being redressed. The current global economic crisis will affect this distribution even further, in particular because the size of the OECD economies has shrunk with around 4 percent in 2009, while most of the Asian economies (such as China and India) have still substantially grown (between 5-8 percent). ${ }^{3}$ This regional shift towards a greater weight of some by the largest Asian economies in the global economy, is an outcome of sustained high growth rates in the Asian continent (except for Japan), which were and are much higher than those in the OECD countries. For example, if we take the period 1991-2001, growth in Japan was on average 1.1 percent, in the United States 3.5 percent, and in the EU 2.4 percent, while developing countries (including China), grew by 4.8 percent (UNCTAD, 2008). In the period 2001-08, during which the world economy was confronted with a trough during 2001-02 (as a consequence of 9/11), Japan grew with 1.7 percent, the US economy with 2.6 percent, and the EU with 2.1 percent per annum (Ibid). In contrast, the developing countries of Asia with China grew with 6.4 percent, while China alone had an average annual growth of 10.3 percent and India 7.7 percent (Ibid).

Table 1: Global GNI (OECD + Developing Countries) in 2007

\begin{tabular}{|l|c|c|c|c|}
\hline & GNI BIn USD & GNI PPP BIn USD & GNI/ Capita & GNI PPP/ Capita \\
\hline World & $52.850,42$ & $65.752,31$ & 7.995 & 9.947 \\
\hline OECD & $37.808,28$ & $35.642,70$ & 39.158 & 36.915 \\
\hline High income & & & & \\
\hline Middle income & $39.685,90$ & $38.386,03$ & 37.572 & 36.341 \\
\hline Low income & $12.393,46$ & $25.666,19$ & 2.910 & 6.027 \\
\hline Least developed countries & 744,29 & $1.929,70$ & 574 & 1.489 \\
\hline East Asia and the Pacific & 383,63 & 935,73 & 494 & 1.171 \\
\hline South Asia & $4.172,76$ & $9.503,13$ & 2.182 & 4.969 \\
\hline United States & $1.338,68$ & $3.853,61$ & 880 & 2.532 \\
\hline Japan & $13.886,42$ & $13.827,20$ & 46.040 & 45.840 \\
\hline China & $4.828,91$ & $4.440,21$ & 37.790 & 34.750 \\
\hline India & $3.126,01$ & $7.150,54$ & 2.370 & 5.420 \\
\hline
\end{tabular}

Source: World Development Indicators Database (April 2009)

3. UNCTAD (2009) is used as reference here. There are quite some conflicting data on the differential impact of the global crisis though. 
Although the Chinese and Indian economies together started to approach the size of the Japanese (or at PPP even approach the US economy) by the midst of the decade, income inequality measured at per capita income levels remains very large. ${ }^{4}$ As can be read from Table 1, average gross national income per capita (2007) ratios between the US, China and India were distributed as 48: 2: 1, while ate PPP prices this was 17: 2: 1.

The spectacular growth rates in the various parts of Central, East, South and Southeast Asia and the Pacific are on average high, but still quite differentiated between various sub-regions, as is shown in Figure 1. These very high growth rates emerged in the current decade, and notably the growth rate of those Central Asian countries which emerged from the former Soviet Union were the highest in the region during the period 2004-2008 (between 10 and 12 percent) ${ }^{5}$, while growth rates of GDP in East and South Asia were consistently between around 8 percent, still much higher than in the OECD region.

\section{Figure 1: GDP Growth in Asian Region}

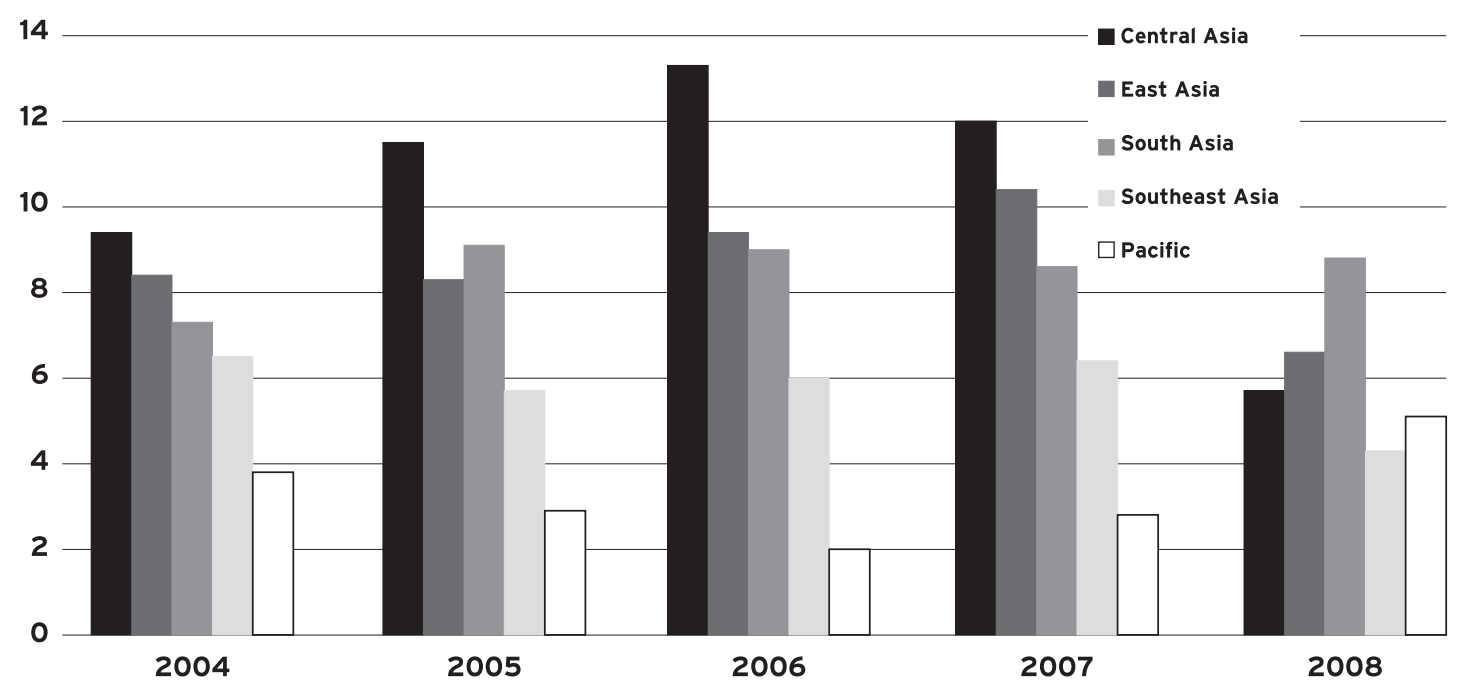

Source: Asian Development Outlook (2008).

Hence, Asia led current global growth until the global economic crisis and continues -albeit at slightly lower levels during the crisis. The differential rates of growth have only become larger as in 2009 the OECD countries were in deep recession, while China and India were growing still quite fast. In particular China showed a speedy recovery to growth rates close to 10 percent, although there are some concerns about 'overheating' (to be seen in higher inflation occurring in early 2010). China has become the new manufacturing centre of the world, to be compared with Manchester during the first industrial revolution, with growth largely being industry and export-led. ${ }^{6}$ In parallel, India

\footnotetext{
4. The differences between per capita income of OECD countries and China or India are still huge, and global income inequality, taking this into account, has possibly increased (see Milanovic, 2005), especially if growing domestic inequality is taken into account.

These high growth rates are mainly to be explained by the spectacular carbohydrate-driven growth rates in Kazakhstan and Turkmenistan.

6. Fischer (2010: 21) however argues that it is mostly processing industry, observing that China has a "subordinate third or even fourth-tier position" within
} 
transforms itself an important service centre, in particular for IT services. China focused on manufacturing exports, for which it also demands more and more industrial inputs, primary commodities and energy sources, while India is already making a gradual transition towards high-tech exports, which generate more value added. Both countries have been influencing the global trade patterns and flows and were also, in the crisis, affected by the dramatic slowdown of the demand for their exports, especially China, which has chosen to boost domestic demand, to complement for the losses incurred in the export sector. The export sector was also the first to recover, positively influencing the resumption of growth of the OECD economies with its renewed high growth in 2010.7

While the US, EU and Japanese economies -in late 2008 and the whole of 2009has been going through the largest economic contraction since the 1929 " $\mathrm{crash}^{\text {", this }}$ crisis had a different impact on China and India. Growth slowed down in both countries, but was still substantially positive growth rates have been kept in the depth of the crisis, where Japan showed a 12.7 percent contraction in the $4^{\text {th }}$ quarter of 2008 and the US economy did so with 6.2 percent. China's growth rate slowed down to 6.8 percent in the same period, while India reported 5.3 percent growth. Nevertheless, even this relatively slower growth rate had dramatic consequences. For example in China, an estimated 20 million workers lost their jobs in the $4^{\text {th }}$ quarter of 2008 and the $1^{\text {st }}$ quarter of 2009. Absorption of rural labour in industrial/urban centres needs a minimal growth rate of 10 percent. Employment was also negatively affected by the dramatic drop in Chinese exports in 2009 (when they still slightly grew, but at a much slower pace than in the previous years, when export growth rates of 20-30 percent/annum had become the standard). Hence, although it seems from the outside that China and India were hardly affected by the global recession, this was not the case. Both the OECD countries in deep recession as well as China, suffering from insufficient growth rates to keep absorbing the enormous migration from rural areas into the cities, choose for huge fiscal stimulus packages, championed by China who provides an enormous boost to its economy the period 2009-2011. ${ }^{8}$

Economic recovery is stimulated in a Keynesian manner, with increased public investment in infrastructural projects, communications and employment generation. It seems that it indeed has stabilized the economy's slowdown, with first signs of recovery towards former high growth rates already seen by the $4^{\text {th }}$ quarter of 2009 . India was somewhat less affected by the global recession, although some export (service) sectors were also hit hard in terms of employment. India has also responded in a less interventionist manner to contain the crisis, but has been able to stabilize its economic growth in 2009-2010, as increased domestic (and in particular rural) demand kept on boosting the economy. India did use fiscal stimulus packages which meant that its relatively low fiscal deficit as share of GDP more than doubles (to above 6 percent) in 2009.

\footnotetext{
East Asian production networks, and that more than 50 percent of exports come from foreign dominated transnational companies in China. Izurieta and Singh (2010), argue correctly that the emergence of China and India and their pattern of industrialization has actually provided positive impacts on the US-economy (contrary to the popular idea that they only pose a threat, in particular to jobs), such as providing cheap consumer goods consumed by low-income US-citizens; apart from the purchase of US-treasury bonds which also avoided lower growth of the US economy.

8. According to UNCTAD (2010): "China has done more than any other emerging economy to stimulate domestic demands.. According to several estimates, Chinese private consumption increased by $9 \%$ in 2009 in real terms, dwarfing all the other major countries' attempts to revive their domestic markets."
} 


\section{Asian trade and the world economy}

Using data provided by Ocampo and Martin (2003) to look at the history of trade, for most of the $20^{\text {th }}$ century, exports were dominated by the industrialized world. In 1973, Europe, North America and other industrialized countries had respective shares of 50.3, 19.1 and 9.6 (total 79.0) percent of world merchandize exports. In 1990, in spite of the implementation of structural adjustment in many developing countries $^{9}$ (and with a greater openness of the OECD countries as part of the GATT agreements), these shares remained stable, with 51.9, 17.0 and 11.0 (total 79.9) percent. By 1998, they had slightly gone down to 47.4, 18.6 and 9.5 (total 75.5) percent (Ibid). In the 2000s this reduction continued, with an increasing share for low and middle income countries. Their growth in exports was largely absorbed by other low and middle income countries, which share went up from 7.1 to 14.3 percent in the same period (very much representing the increased role of Chinese exports in world merchandise trade). The exports to high income countries only grew from 17.0 to 20.9 percent. The latter, however, continues to grow, and if services exports would be taken into account, the increase would be even more visible.

In Table 2, which shows inter-regional merchandise trade for 2007, just before the global economic crisis started to unfold, we can note that Asia's trade (including Japan) as share of total exports represents already 27.9 percent, well beyond the share of North America, but still below that of Europe, which -by the way- is largely trading within Europe itself (73.5 percent of all regional trade), while this share is less than half (49.7 percent) for Asia.

\begin{tabular}{|c|c|c|c|c|c|c|c|c|c|}
\hline \multirow[b]{2}{*}{ Billions of USD } & \multicolumn{9}{|c|}{ DESTINATION } \\
\hline & & $\varangle$ & త্র & 号 & $\frac{n}{U}$ & 峞 & $\stackrel{\omega}{\Sigma}$ & 管 & $\begin{array}{l}\text { 흔 } \\
\text { 은 }\end{array}$ \\
\hline \multicolumn{10}{|l|}{ ORIGIN } \\
\hline World & & 2.517 & 451 & 5.956 & 397 & 355 & 483 & 3.294 & 13.619 \\
\hline North America & NA & 951 & 131 & 329 & 12 & 27 & 50 & 352 & 1.854 \\
\hline South and Central America & SCA & 151 & 122 & 106 & 6 & 14 & 9 & 80 & 499 \\
\hline Europe & EUR & 459 & 80 & 4.244 & 189 & 148 & 153 & 434 & 5.772 \\
\hline Commonwealth of Independent States & CIS & 24 & 6 & 288 & 103 & 7 & 16 & 60 & 510 \\
\hline Africa & $\mathrm{AF}$ & 92 & 15 & 168 & 1 & 41 & 11 & 81 & 424 \\
\hline Middle East & ME & 84 & 4 & 108 & 5 & 28 & 93 & 397 & 760 \\
\hline Asia & AS & 756 & 92 & 715 & 80 & 91 & 150 & 1.890 & 3.800 \\
\hline
\end{tabular}

\footnotetext{
Structural Adjustment was initially expected to boost foreign trade through a rapid liberalization of markets and the reduction of tariffs. However, it did not translate in an improvement of relative shares for most developing countries.
} 


\subsection{From Mao to the WTO}

The growing importance of Chinese exports is extraordinary, especially considering that China started as a very isolated economy in the late period before the reforms in 1978. Growth during the 1980s was largely endogenous, based on a rapid growth of the agricultural sector and rural savings. At that era the first steps towards a export-led economic strategy were becoming visible in some of the later Asian Tigereconomies, albeit mixed with import substitution industrialization. In contrast, growth of the Chinese economy was largely endogenous until the early 1990s. It was primarily investment-led growth, and in the early stages, after the introduction of the household responsibility system in agriculture, financed by rapidly improving peasant incomes and household savings. Since the early 1990s, Foreign Direct Investment (FDI) started flowing into the country, which followed sustained and rapid growth, rather than causing it (see Spoor, 2007). However, FDI soon did become much more important, in particular when it became a crucial mover of more technology-intensive and innovative production sectors, hence a catalyst for further modernization. Exports became more and more the motor of its growth strategy, and during much of the 1990s, China followed a strategy of export promotion (rather than liberalization), with import protection diminishing gradually, in order to prepare for the membership of the WTO, which was realized in 2001 (Anderson, Huang and Ianchovichina, 2004).

Since the mid-1990s, China's exports (and in its shadow those of India as well, although at much lower levels still, see Acharya, 2009), have reached yearly growth levels which are much higher than any other country (see Table 3). Its growth rates have been stable at around 25 percent per annum since 2001 until the current global economic crisis. Exports from China grew by rates of 10-30 percent per annum and at 10-20 percent for India during the years 2001-2008 (see Table 3). Similarly, but overall less, imports also grew in a spectacular manner. Faster growth of imports than exports has meant that India gradually increased its trade deficit (Ibid.).

\begin{tabular}{|c|c|c|c|c|c|c|}
\hline \multirow[b]{2}{*}{ (\% per annum) } & \multicolumn{6}{|c|}{ Export Volume } \\
\hline & 1996-2000 & $2001-2004$ & 2005 & 2006 & 2007 & 2008 \\
\hline World & 7 & 6 & 6 & 9 & 6 & 4 \\
\hline Developed economies & 7 & 4 & 5 & 8 & 4 & 3 \\
\hline \multicolumn{7}{|l|}{ of which: } \\
\hline Japan & 6 & 6 & 5 & 12 & 7 & 5 \\
\hline United States & 7 & 1 & 7 & 11 & 7 & 6 \\
\hline Europe & 7 & 5 & 6 & 9 & 3 & 3 \\
\hline Developing economies & 8 & 9 & 9 & 11 & 8 & 5 \\
\hline \multicolumn{7}{|l|}{ of which: } \\
\hline China & 12 & 26 & 27 & 25 & 22 & 13 \\
\hline India & 8 & 13 & 16 & 10 & 13 & 7 \\
\hline S-E Europe and CIS & 1 & 9 & 0 & 5 & 7 & 19 \\
\hline
\end{tabular}

Source: UNCTAD $(2008,2009)$ 
Asia's (but in particular China's) fast growing exports have of course meant that the trade balance in most of the region has become very positive, except for South Asia, which has a large negative trade balance under the influence of a trade gap for India (which in 2007 was 90.0 billion USD; see for regional trade balances Table 4). The latter might be explained by the much smaller share in terms of heavy industry (and manufacturing industry in general) in comparison to countries such as China and the Tiger economies, and hence its dependence on imports of intermediate goods.

\begin{tabular}{|l|c|c|c|c|c|}
\hline Table 4: Trade Balance Asian Regions (2004-2008) \\
\hline USD Million & & & & & \\
\hline & 2004 & 2005 & 2006 & 2007 & 2008 \\
\hline Central Asia & 7.179 & 14.222 & 23.971 & 30.477 & 62.483 \\
\hline East Asia & 104.505 & 178.597 & 255.955 & 354.243 & 351.442 \\
\hline South Asia & -44.456 & -68.340 & -85.048 & -115.438 &.. \\
\hline Southeast Asia & 75.512 & 74.624 & 107.904 & 116.464 & 86.747 \\
\hline
\end{tabular}

Source: ADB (2009)

It is also important to note that in the Central Asian region and the Caucasus, only for Kazakhstan and Azerbaijan the trade surplus is growing because of rapidly expanding oil exports and the high prices for oil. For all other countries in this region the absence of those resources or a thriving manufacturing sector provides pressures for growing imports, which led to only slightly positive trade balances in the early part of the decade (before the windfall profits gained from oil and natural gas). This is contrary to what is visible for East Asia (dominated by China), where the trade surplus became nearly 351.4 billion USD in 2008, in which China alone covered for 315.4 billion USD (Table 4, and ADB, 2009).

Taken together, the success of the South and East-Asian region in terms of export performance is spectacular compared to the performance of Latin America and the Caribbean (LAC), Africa, and West Asia. The Asian miracle of the 1980s was already the success of the interventionist developmental states of Japan and the Tiger economies, with an appropriate mix of import substitution and export orientation. ${ }^{10}$ The combined Asian region established much quicker a predominance of manufactured exports than any of the other developing regions. LAC is also partly undergoing this transition, but is doing so at a much slower pace (UNCTAD, 2008). LAC has also been struck much more severely by the global recession, which has particularly hit manufactured exports, providing a drawback to the above described process of industrial transformation within the export portfolio.

In the developing world (or the low-and middle income countries), comparing between continents it is clear that East and South Asia have been making the transition to higher value exports and moving away from fuels and non-fuel primary exports,

10. It is always good to remember what Alice Amsden argued that fast growth and industrialization took place precisely because South Korea had their prices deliberately "wrong" (see Amsden, 1992). 
while these commodities are still dominant in the exports portfolio of Africa and West Asia (see UNCTAD, 2005). While Africa was still for 50.6 percent dependent on fuels in exports during the period 1999-2003, this was 72.2 percent for West Asia (Middle East), and only 16.2 percent in LAC. For South and East Asia together this only represented 4.9 percent, as most countries are energy importers. In the non-fuel primary commodity exports, the shares for the other regions went down to respectively 24.0, 6.1 and 25.7 percent. For the South and East Asia region, this dropped to 9.1 percent. Finally, the share of manufactured exports increased for Africa, West Asia and Latin America to respectively 23.0, 21.0 and 56.6 percent, while this was 84.8 percent in the 1999-2003 period for South and East Asia, a development primarily pushed by China. The transition that the South and East Asian region has made in this respect has been faster than that of any other developing region. This becomes especially apparent when comparing 1980-83 with the 1989-92 averages, and slightly less so between the latter period and 1999-2003, when LAC seems to catch up in terms of the importance of manufactured goods in total exports (UNCTAD, 2005). In recent years LAC has had enormous windfall profits and income from price hikes in primary commodities, in part caused by the growing demand generated by the Asian economies. This has unexpectedly re-emphasized the pre-dominance (for some countries) of primary commodity exports.

Elaborating on some of the Asian economies and this qualitative transformation of exports there are some long-term trends mentioned by ADB (2006). On the one hand, to show the importance of manufactured exports, we can note the increasing share of electronics in the export value. Japan from 1965 to 2003, raised this share from 7.5 to 22.6 percent, South Korea, during the same period, from 0.9 to 35.8 percent, while a "late comer" such as China has managed to do the same, from 3.4 to 30.3 percent, within a much shorter time-span, namely from 1987 to 2003 . As stated above, India is much less involved in manufacturing exports, and only lifted its share of electronics exports in the total export value from 0.8 to 1.9 percent since 1975 (ADB, 2006). On the other hand, China dropped from 37.7 to 9.2 percent its share of primary commodities in its exports (during the period 1987-2003), while for India this share went down from 55.1 to 23.0 percent over an even longer period (1975-2003). These trends have continued in the years to follow (see ADB, 2009).

\subsection{China's insatiable appetite for raw materials}

As another aspect of the rapid changes in international trade, Asian developing economies, such as China and to a lesser extent India, have been strongly influencing the rising additional demand in the world markets for oil, metals and minerals, and primary agricultural commodities, such as soybeans (primarily produced in the USA and Brazil). The appetite for resources of these rapidly emerging economies has been boosting world market prices for commodities such as oil, steel, copper and tin, which provides additional income for the producing countries ${ }^{11}$, such as in oil when

11. However, these windfall profits and increased inflows of FOREX also meant for some of the exporting countries effects of 'Dutch Disease', strengthening their traditional role of primary commodity exporter. 
during 2008 the price of crude skyrocketed to a level of more than 140 USD/b. During the global economic crisis of 2008-2009, prices dropped again, but it can be expected that with economic recovery, an upward pressure on primary commodity prices will be felt again, which is already noticeable in early 2010, at the time of final revisions made to this paper.

China has been signing many bilateral agreements with African and Latin American countries, to safeguard its energy and input needs for the coming decades, while the Indian economy might start to express similar needs, although not as profound as it is still less industrialized and in that field possibly with a time-lag of between 5 to 20 years behind China. ${ }^{12}$ This increase in demand for energy resources and other primary commodities has slowed down during the 2008-2009 crisis, although China has launched an ambitious investment program to boost domestic demand, which seems to be working. ${ }^{13}$

\section{Figure 2: Increased Developing Country Demand (2003-04)}

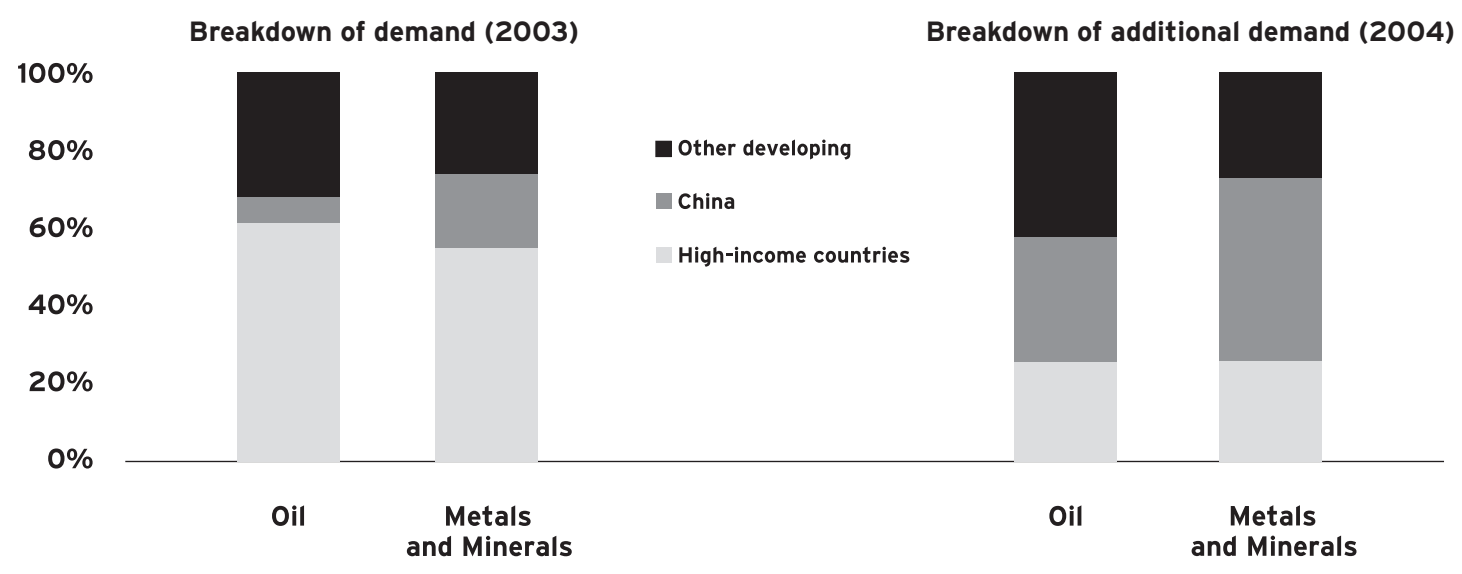

Source: GDF (2005). http://siteresources.worldbank.org/INTGDF2005/Resources/gdf05complete.pdf

China is also investing in energy efficiency, and environmental measures to contain increasing pollution, measures which in the future might well reduce the projected incremental demand that is projected at the moment. While in 1980 primary oil demand was still largely dominated by the OECD economies (41.8 millions barrels / day versus all the developing countries together only using 11.3 million barrels / day), this picture is rapidly changing. By the year 2000 the oil demand from the side of developing countries already had risen to 23.1 million barrels/day, with China alone represented by 4.7 million barrels / day (IEA, 2007). In Figure 2, it can be seen how some years further (in 2003) China's demand for oil accounted for 7.0 percent of world exports, while in metals and minerals this was already 19.1 percent.

\footnotetext{
2. Acharya (2009) argues that there is also a permanent qualitative difference in growth models between China and India. Hence, not only there is a substantial time-lag in development, but he states that India will not go through a similar industrialization, and hence will influence world demand for energy resources in a different manner.

13. In the first quarter of 2010 China's growth was already close to 10 percent
} 
These shares have been rapidly growing in the years to follow. This can be seen by looking at additional demand, which in 2004 came for oil for 31.2 percent came from China, and for even 47.0 percent for metals and minerals, caused by the rapidly growing Chinese industrial sector (IEA, 2007). It has been estimated that this trend has continued and that in 2010 the demand for oil in the OECD countries is around 49.0 million barrels, while in the developing countries this has grown rapidly to $33.7 \mathrm{mil}-$ lion barrels / day (with China standing for 9.0 and India for 3.1 barrels / day alone). The expected demand from the side of the Chinese economy in 2030 is estimated to be 16.5 barrels / day, just more than half of the US demand (Ibid.).

The non-oil exporting (and energy-poor) developing countries, which form the majority, will be negatively affected by the increased demand for carbohydrates in the next few decades, as rising prices will increase their import bills. While at the same time development finance will be less available, this might well create a financial squeeze for many of the developing countries, which is a new imbalance that is the indirect consequence of the structural re-balancing of the world economy as was analyzed in section two.

\section{Old and new global imbalances}

The rapid expansion of trade, and in particular of exports, in and from the East Asian region is one of the most important reasons for the increasing surpluses on the current account (CA) of a number of these Asian economies, in particular China and Japan (IMF, 2008). Looking more broadly, in Figure 3 an overview is depicted for 20072008 of the CA balances of a group of OECD (and CEE) countries which large deficits, which are compared with others which have large surpluses, such as Germany, the CIS and the Middle East (because of oil revenues), and the already mentioned China and Japan (Figure 3).

Figure 3: Current Account Balances (2007-08)

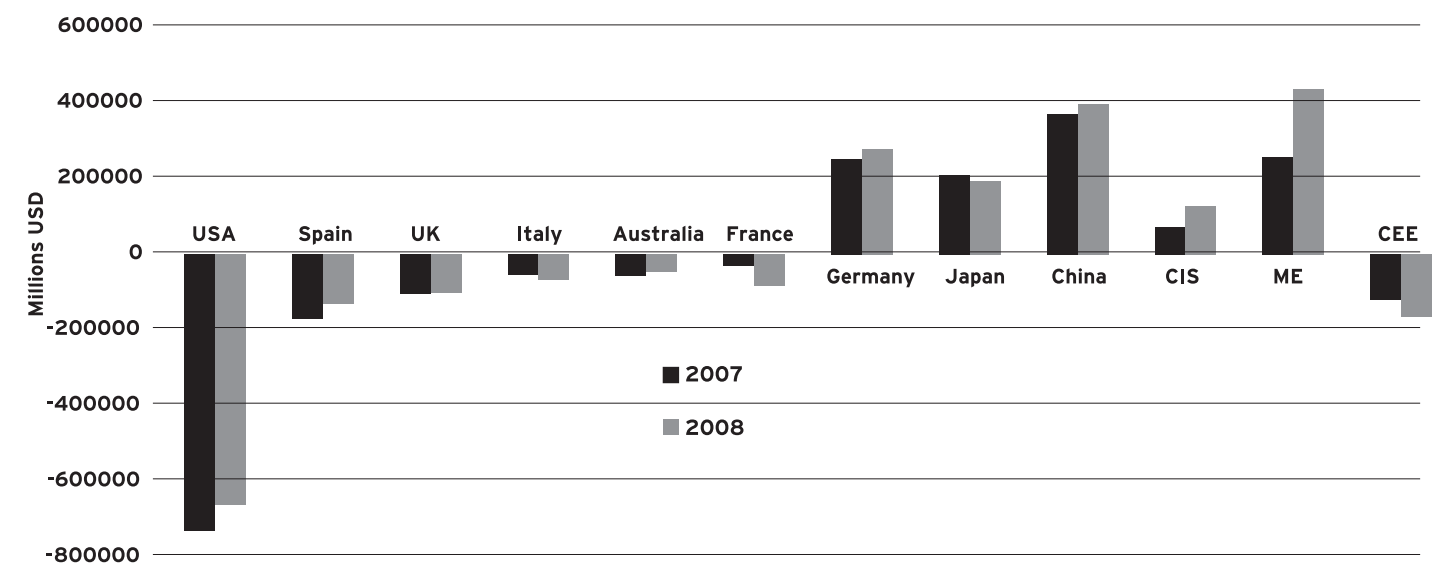

Source: ADB (2009) 
Apart from the above mentioned Asian economies, there are a number of European countries which also have substantial CA surpluses, such as Germany, Norway, and Sweden. However, at the other side of the spectrum, apart from the United States, there is a group of Western economies, formed by Spain, United Kingdom, France, Australia and Italy having substantial CA deficits.

The accumulated deficit in 2008, held by these six countries, was estimated at 1,094 billion USD, with the US accounting for an estimated and staggering 664 billion USD. If the Central and Eastern European countries are added (which have been hit very hard during the 2008-2009 crisis), the CA deficit accumulates to 1,258 billion USD. In comparison, Germany, China, Japan, the CIS (in particular Russia) and the Middle East, the mentioned CA surplus countries, held an accumulated surplus of 1,439 billion USD in 2008 (ADB, 2009). The CA deficits have been reducing in 2009, but this was mainly caused by the recession rather than a structural change in the imports and exports of the OECD countries.

As was shown in the first section, sustained growth of the Asian economies, fuelled by a growth of exports, is actually redressing a long-standing imbalance, in which the global economy is largely dominated by a small number of high income countries (the OECD group). However, the export growth (and the movement of FDI) has contributed to global financial imbalances which emphasize a new division into two groupings. One is "headed" by the United States which has built up an unprecedented CA deficit, with some other OECD economies (including the CEE countries) that have much smaller deficits, while the other group, led by some Asian economies, in particular by China and Japan shows an increasing CA surpluses, while furthermore some European countries, in particular Germany, and furthermore Russia belong to this group. The crisis and the differential impact of contraction of the global economy possibly re-iterate this global imbalance.

Although in theory there is no problem, as long as Current Account and Capital Account balance, in reality things are not that simple (McKinley, 2006). Before the credit crunch and financial crisis there was already an increasing pressure on the USA dollar, but the US government looked particularly at China, asserting pressure to appreciate its currency. However, it seems that the latter is only happening very gradually, not to endanger the excellent export performance of the Chinese economy has had until now, and particularly its rapid recovery late 2009 and early $2010 .{ }^{14} \mathrm{~A}$ further realignment of the Dollar-RMB exchange rate might be desirable, but it is not going to transform the structural foundations of the imbalances, such as the "over-consumption" in the US (Akyüz, 2010).

As a consequence of the global financial imbalances there is a peculiar situation in which inverse financial streams have emerged, from low- and middle income

14. Early 2010 domestic inflation was suddenly surging, which could be a sign of overheating of the Chinese economy. A effort to slowdown (stimulated by increased interest rates to contain inflation) could include a further appreciation of the exchange rate. 
countries (such as China) to high income countries, principally the USA, excluding other (weaker) developing countries from these financial flows (McKinley, 2006; Izurieta and McKinley, 2006). As growth has slowed down in 2008 and a full-blown contraction took place in the OECD (and other) regions, financial flows will further reduce, or partially directed to the Western economies in crisis and domestically used, with continued exclusionary effects for the weaker developing countries.

\subsection{International Reserves and their Destination}

International reserves have been increasingly accumulated by China and Japan (and to a much lesser extend by the USA and Russia). These two Asian economies hold more than half of the world's international reserves, emphasizing even more the global financial imbalances. In particular the reserves accumulated by China, but also in other Asian economies are increasingly hoarded, and converted in (relatively low-performing US-treasury bonds, see Dollar, 2009), rather than invested in the domestic economy, to boost consumer demand, which could -at least in the long run- redress some of the existing global financial imbalances. It has been suggested that this relatively cautious behaviour of Asian policy makers has been inspired by the devastating influence of the previous financial crisis in 199798, which had its origin in a collapse of banking institutions in the region itself. International financial institutions were incapable to intervene, and when they did their actions were largely contra-productive (Stiglitz, 2003). Holding large international reserves has become a new form of self-defence of the emerging Asian economies (Vos, 2010).

McKinley (2006) argues that the US-dollar reserves held in Asia help to "finance the gargantuan US Current Account deficit", while:

Many of the developing countries holding large foreign-exchange reserves, particularly those in Asia, have systematically tried to sterilize their impact on their domestic money supply. This has aborted the expansion of domestic credit, which could have stimulated private investment and closed the gap of investment with domestic savings.

This has led to something rather counter-intuitive to happen, namely finance moves to the economy which least needs it (Ibid.). Since the global economic crisis of late 2008- early 2009 this is even more true, and it can therefore be understood that Mrs. Hilary Clinton, the US Secretary of State of the new Obama administration, went first to China with the preoccupation that it would continue to finance the US-deficit. China may be wondering whether the US is 'still good for its money', i.e. the Treasury Bonds, but on the other hand will continue to finance the gap on the US Current Account, because of obvious inter-dependency of the two economies. 


\section{Conclusion}

The structural global imbalance of high income versus low- and middle income countries and their traditional dominance in international trade has been positively addressed by the rapid growth of the developing economies in East, South and Southeast Asia. This is likely to continue in the decades to come. In 2010 China has already become the second economy of the world, taking the place of Japan. Before the global economic crisis emerged, Asia's trade volume (including that of Japan) had overtaken already overtaken that of the US, and is approaching the volume of EU trade. Furthermore, although there are still very large differences in per capita income, the fast growing economies of China and India have the potential to become larger than respectively the US or Japanese economies within several decades, leading to a multi-polar world economy with the economies of the US, EU and Asia as the most important ones. However, there are other global financial imbalances that have emerged in parallel with this development. Most pertinent amongst these is the differentiation between current (CA) surplus and CA deficit economies, with global savings moving towards the economy (the USA), now even more than before the global crisis emerged. As a consequence of fast growth, positive trade balances and influx of FDI, China (with Japan) has built up very positive current account balances. The emerging Asian economies have actually hoarded the international reserves they have accumulated in the past decade, sterilizing the effects on their domestic economies, and not using them to stimulate domestic consumption. However, rather than criticizing the Chinese for undervaluation the RMB (Yuan), the CA deficit countries need to become more competitive, innovative and investment rather than consumption-led and export-oriented.

Finally, new imbalances are emerging, such as the expansion of demand for raw materials (energy, metals, minerals, and agricultural commodities) generated by China and to a lesser extend India, until the eve of the global crisis, and in the years after the current global recovery, is also benefiting the carbohydrate exporting development countries. However, this could easily lead to 'Dutch Disease' effects for these exporting economies, withholding them from becoming competitive in manufactured commodity markets, a transition that just had started in the past decades. It can also mean that some middle-income developing countries, such as Argentina and Brazil are becoming (even more than they are already) main suppliers of agricultural raw materials for Developing Asia, be it for the growing animal husbandry sector to feed the expanding middle classes, or for the production of bio-fuels. Energy-poor developing countries will feel mostly detrimental effects from this development, as energy prices will rise again, and their import bills as well. China's demand for raw materials has temporarily slowed down in 2008. However, its domestic demand for inputs in industries has been stimulated by the large scale stimulus package, which is focused on infrastructural investments.

The global imbalances which have been analyzed in this paper, in particular the financial imbalances which influence large 'inverse' capital flows towards the slowgrowing CA-deficit and consumption-led western economies, have to be redressed, 
as these are detrimental for other developing countries, in particular those who are dependent on energy and primary commodity imports. However, the recovery from the global crisis, and the public finance that has been utilized to bail out the banks or finance the stimulus packages, will make this process of restoring balances even longer, negatively affecting the poorer developing countries. China and India will likely recover rapidly their previous rates of economic and export growth, as the first signs of 2010 already seem to indicate. The high income countries are benefiting substantially from the fast growth of China and India. Nevertheless, global financial imbalances will not be redressed if China will not direct more of its reserves towards the domestic economy in terms of increasing consumer demand, while the US (and some of the other CA-deficit OECD economies) should redirect their growth models to more savings (and investment)-based, more competitive and export directed economies (Dollar, 2009; Vos, 2010). 


\section{References}

Acharya, S. 2009. In China, India and Beyond: Development Drivers and Limitations, pp. 23-45. Cheltenham: Edward Elgar for the Global Development Network.

Akyüz, Y. 2010. Global Economic Prospects: The Recession May Be Over But Where Next?. Research Paper No. 26, Geneva: South Centre.

Amsden, A. 1992. Asia's Next Giant: South Korea and Late Industrialisation. Oxford: Oxford University Press.

Anderson, K., Jikun Huang and Elena Ianchovichina. 2004. Will China's WTO accession worsen farm household incomes. China Economic Review, 15: 443-456.

ADB. 2009. Asian Development Outlook. Manila: Asian Development Bank.

ADB. 2006. Asian Development Outlook. Manila: Asian Development Bank.

Arnim, R. von. 2007. Short-Run Adjustment in a Global Model of Current Account Imbalances. Working Paper, New York: New School University.

Dinello, N. and W. Shaoguang (Eds.) 2009. China, India and Beyond: Development Drivers and Limitations. Cheltenham: Edward Elgar for the Global Development Network.

Dollar, D. 2009. Asian Century or Multipolar Century? In China, India and Beyond: Development Drivers and Limitations, pp. 46-69. Cheltenham: Edward Elgar for the Global Development Network.

Fischer, A. 2010. Is China Turning Latin? China's balancing act between power and dependence on the wave of global imbalances. Working Paper, 496, International Institute of Social Studies, Erasmus University Rotterdam, February.

Haan, A. de. 2009. Will China Change International Development As We Know It? Working Paper, 475, The Hague: Institute of Social Studies.

IMF. 2009. World Economic Outlook Database, accessed through http://www.imf.org

IEA. 2007. World Energy Outlook: China and India Insights. Paris: International Energy Agency.

Izurieta, A. and T. McKinley. 2006. Addressing Global Imbalances: A Development Oriented Policy Agenda. Working Paper, 23. Brasilia: UNDP Poverty Centre.

Izurieta, A. and A. Singh. 2010. Does Fast Growth in India and China Help or Harm US Workers? Journal of Human Development and Capabilities, 11: 115-141.

Mahbubani, K. 2008. The New Asian Hemisphere: The Irresistible Shift of Global Power to the East. New York: Public Affairs.

McKinley, T. 2006. The Monopoly of Global Capital Flows: Who Needs Structural Adjustment Now?, Working Paper, 12, Brasilia: UNDP Poverty Centre.

Milanovic, B. 2005. Worlds Apart: Measuring International and Global Inequality. Princeton: Princeton University Press.

Ocampo, J. A. and J. Martin (Eds.) 2003. Globalization and Development. A Latin American and Caribbean Perspective. Stanford University Press, for Eclac and the World Bank.

Spoor, M. 2007. Growth and Regional Inequality in Asia's "New Dragons". In M. Spoor, N. Heerink and F. Qu (Eds.). Dragons with Clay Feet? Transition, Sustainable Land Use and Rural Environment in China and Vietnam, pp. 93-108. Lanham and Oxford: Rowman and Littlefield, Lexington Books.

Stiglitz, J. 2003. The East Asian Crisis: How IMF Policies Brought the World to the Verge of a Global Meltdown. In Globalization and its Discontents, pp. 89-132. New York: Norton. 
UNCTAD. 2005. Trade and Development Report. Geneva: United Nations Commission for Trade and Development.

UNCTAD. 2008. Trade and Development Report. Geneva: United Nations Commission for Trade and Development.

UNCTAD. 2010. Global monetary chaos: Systemic failure need bold multilateral responses. Policy Brief, 12, March 2010. Geneva: United National Conference on Trade and Development.

Vos, R. 2010. New Directions for Globalization in Times of Crisis. Mimeo, New York. 

